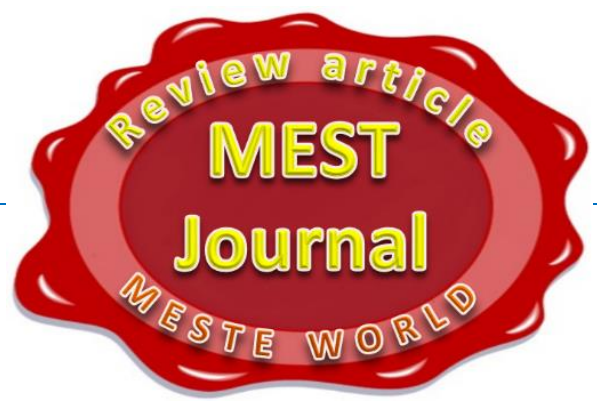

\title{
IS ECON 101 KILLING AMERICA? A CRITIQUE OF ATKINSON AND LIND, AND BOETTKE
}

\section{Walter E. Block}

Harold E. Wirth Eminent Scholar Endowed Chair and Professor of Economics, Joseph A. Butt, S. J. College of Business, Loyola University New Orleans, USA

\begin{abstract}
Atkinson and Lind (2013) fire a shot at the good ship economics; actually ten shots. They claim that courses in introductory economics ("econ 101") pass off "ten myths" on unwary students, and public policy practitioners. And what are these "ten myths" we are warned about. They are as follows: Myth 1: Economics is a science. Myth 2: The goal of economic policy is maximizing efficiency. Myth 3: The economy is a market. Myth 4: Prices reflect value. Myth 5: All profitable activities are good for the economy. Myth 6: Monopolies and oligopolies are always bad because they distort prices. Myth 7: Low wages are good for the economy. Myth 8: "Industrial policy" is bad. Myth 9: The best tax code is one that doesn't pick winners. Myth 10: Trade is always win-win. Atkinson and Lind (2013) liken modern economics to the church of the middle ages, in terms of misleading the public. Boettke (2013) is an attempt to refute Atkinson and Lind (2013) which misconstrues Austrian economics in several important ways. The present paper is a rejoinder to both of these publications.
\end{abstract}

Keywords: Economics, teaching, myths, praxeology, Austrian economics, science, profits, equilibrium, ceteris paribus, normative and positive economics

\section{() MESTE NGO}

\section{JEL Category: A, A1}

\section{INTRODUCTION}

Atkinson and Lind (2013) offer a frontal attack on economics as it is taught in the modern era, at least at the introductory level. It would appear that dismal scientists "have been anything but shy about asserting their authority," and have unjustifiably seized "a virtual monopoly on

Address of the author:

Walter E. Block

帮” wblock@loyno.edu economic policy advice." Economists have long been misleading the public, and it is time, it is past time, they were taken down a peg or two, and these authors are just the men to undertake this task. *

Atkinson and Lind (2013) liken contemporary economists to Middle Age Churchmen with a bad case of hubris. They state in this regard "... unlike some disciplines, which acknowledge that there's

* All quotations from these authors are mentioned in this one article of theirs. 
a huge gap between the scholarly knowledge and policy advice, economists have been anything but shy about asserting their authority."

These authors offer "ten myths" that economists have foisted upon their students, the general public and policy makers. In section II we consider and reject all of their critiques on these grounds. Boettke (2013) is a rejoinder to Atkinson and Lind (2013). In it this author attempts to defend the dismal science against these fallacious attacks. In doing so, he engages in an important fallacy of his own. Section III is devoted to a critical analysis of Boettke (2013). We conclude in section IV.

Before we begin our examination of the case against economics by these authors, let us consider a few words of background. Atkinson and Lind $(2013)^{1}$ launch their attack on neo-classical economics. I write from an Austrian perspective, not the mainstream one rejected by AL. Boettke (2013) has some Austrian roots, but misconstrues his own supposed principles.

What is the main difference between the two schools of economic thought? Very briefly, conventional economics sees this discipline along the lines of an empirical science. Hypotheses are proposed, statistical tests are devised. If successful, the hypothesis is tentatively accepted, barring any further disproof. There is no such thing as any scientific law, whether in economics or physics. There are only hypotheses that have withstood many examinations. For orthodox economics, prediction is the be all and end all of economics. If your model of the world can predict better than others can, then it is better than these others; if not, not (Friedman, 1953).

For Austrians in sharp contrast, there are indeed economic laws. These cannot be "tested," only illustrated. If econometric findings appear to be incompatible with an economic law, there is something wrong with the former, not the latter.

Here are some examples offered by Hoppe (1995):

"Whenever two people $A$ and $B$ engage in a voluntary exchange, they must both expect to profit from it. And they must have reverse preference orders for the goods and services exchanged so that $A$ values what he receives from $B$ more highly than what he gives to him, and $B$ must evaluate the same things the other way around.

Or consider this: Whenever an exchange is not voluntary but coerced, one party profits at the expense of the other.

Or the law of marginal utility: Whenever the supply of a good increases by one additional unit, provided each unit is regarded as of equal serviceability by a person, the value attached to this unit must decrease. For this additional unit can only be employed as a means for the attainment of a goal that is considered less valuable than the least valued goal satisfied by a unit of such good if the supply were one unit shorter.

Or take the Ricardian law of association: Of two producers, if $A$ is more productive in the production of two types of goods than is $B$, they can still engage in a mutually beneficial division of labor. This is because overall physical productivity is higher if A specializes in producing one good which he can produce most efficiently, rather than both A and B producing both goods separately and autonomously.

Or as another example: Whenever minimum wage laws are enforced that require wages to be higher than existing market wages, involuntary unemployment will result.

Or as a final example: Whenever the quantity of money is increased while the demand for money to be held as cash reserve on hand is unchanged, the purchasing power of money will fall."

Here are some more examples: There is a tendency for profits in all industries to equalize, assuming away differential risk. There is a tendency for the price of each item to be the same. Profits equal zero in equilibrium (Block, 1973, 1980, 1999; Batemarco, 1985; Fox, 1992; Hoppe, 1989, 1991, 1992, 1995, 2006; Hulsmann, 1999; Mises, 1969, 1998; Polleit, 2008, 2011; Rizzo, 1979; Rothbard, 1951, 1957, 1960, 1971, 1973,

\footnotetext{
1 Hence, A\&L.
} 
1976, 1997a, 1997b, 1997c, 1997d, 1993; Selgin, 1988).

These are all synthetic apriori statements: necessarily true, but not mere tautologies that indicate, merely, how we use words. These statements give us valuable knowledge of how the economy actually works, and they cannot rationally be denied.

As for prediction, in the Austrian or praxeological approach, there is no such thing. Economic law only applies ceteris paribus, and ceteris is never paribus in the real world. Nevertheless, knowledge of economic law does indicate how the economy works. Praxeologists can of course predict the future of the economy, but not qua Austrians, only as historians, or journalists.

With this introduction, we are now ready to consider the case made by A\&L to the effect that "Econ $101 \ldots$ leads policymakers astray." Let us now consider their "reasoning."

\section{ATKINSON AND LIND}

\section{Myth 1: Economics is a science.}

"The way economists maintain stature in public policy circles is to present their discipline as a science, akin to physics." This is indeed true, but only for the mainstream, not Austrian economics. However, praxeologists join their neo-classical brethren in maintaining that economics is indeed a "science," in the sense of an organized, disciplined body of thought, promoting systemized knowledge.

However, A\&L are having none of this. According to them: " $\ldots$ if economics is really a science which implies only one answer to a particular question - why do 40 percent of surveyed economists agree that raising the minimum wage would make it harder for people to get jobs while 40 percent disagree?"

But this is highly problematic. A\&L rely on Ruccio (2013) for this conclusion, but the latter puts the question to his respondents ${ }^{2}$ in a particularly pusillanimous manner. He asks of them to either

2 Another difficulty is the panel of "experts" of whom they pose this question. For a critique, based on a biased sample, see Caplan, 2012. strongly or weakly agree, or be unsure, about this claim: "Raising the federal minimum wage to $\$ 9$ per hour would make it notably harder for lowskilled workers to find employment."

There is no more vociferous critic of the minimum wage than the present author (Block, 2000, 2001; Block and Barnett II, 2002; Block, Dauterive and Levendis. 2007; Greene, Henry, Nathanson and Block, 2007; McCormick and Block, 2000; Schuldt, Woodall and Block, 2012; Sohr and Block, 1997). My numerous critiques are on the ground that this law creates unemployment amongst the unskilled. But even I would have great difficulty in strongly agreeing with this particular statement. I am not at all sure that the unemployment rate would "notably" increase due to a boost in the level at which this law is pegged. This is because I have no strong opinions as to how many workers have discounted marginal revenue products between $\$ 9.00$ and the present law stipulating $\$ 7.25$. I have no doubt that in equilibrium all of them would be unemployed, of course. A far better question would have been: "Ceteris paribus, will a minimum wage set at any level tend to unemploy workers with productivity of less than that amount." To be sure most economists, Austrian or mainstream, would support such a statement.

And this goes for Joseph Stiglitz himself, Nobel Prize winner and major supporter of this legislation as a means to increase wages for the unskilled. He signs petitions to this effect, but his textbook (Vuk, 2006) contains the consensus view on this despicable legislation within the profession. That is, of course, minimum wage laws create unemployment for workers with lower productivity than that stipulated by law. (For more on the strong consensus amongst economists on minimum wage legislation, see Alston, Kearl and Vaughan, 1992; Block and Walker, 1988, Caplan, 2007; Frey, Pommerehne, Schneider and Gilbert, 1984; Fuller and Geide-Stevenson, 2003; Gordon and Dahl, 2013; Wolfers, 2012). In any case, just because there is widespread disagreement this does not mean that a particular discipline is not scientific. Climate science is certainly a science,

Paradoxically, this panel usually demonstrates consensus amongst economics, not the lack of same (Wolfers, 2012) 
and yet there is much disagreement amongst meteorologists. At times in the past and even upon occasion in the modern era there has been little consensus within the following sciences: genetics, astronomy, physics, chemistry and biology.

\section{Myth 2: The goal of economic policy is maximizing efficiency.}

In the view of A\&L "Economists have one overarching principle that shapes their advice: maximize 'efficiency."' But this is an Econ 101 confusion between the normative and the positive. The only economic "principle" that exists is to explain and understand economic reality. Economics is a positive science, not a normative one (Block and Cappelli, 2013). "Economic policy," presumably, refers to the actions of the government. Economics, per se, has no view on that either, as this too is a normative concern. The dismal science is limited to unearthing cause and effect relationships in its area of study. "Should the government institute rent control?" No economist worthy of his salt can answer that. That is a matter of values, not economics. The economist, qua economist, must limit himself to explaining what the effects of such a law would be.

$A \& L$ also err in their claim that somehow "inefficiency - in the sense of disruptive innovation" a la Schumpeter is more efficient than market resource allocation. No. Ideally, a properly functioning economy can have both at the same time: an optimal amount of new innovation, coupled with efficient allocation at each point in time. There is no necessary conflict between the two desiderata.

In any case, as members of the public choice school (Buchanan and Tullock, 1962) never tire of reminding us, the goal of economic policy is to feather the nests of politicians, bureaucrats, crony capitalists and others of their ilk, not to "promote efficiency."

\section{Myth 3: The economy is a market.}

According to A\&L, "In the world of Econ 101, 'the economy' is usually treated as a synonym for 'the

\footnotetext{
${ }^{3}$ Note the very objectionable scare quotes around this phrase.
}

market.' But an enormous amount of economic activity takes place outside of competitive markets dominated by for-profit, private firms." This charge is just plain erroneous. I defy these authors to point to any textbook, any textbook at all, that fails to mention "governments ... households ... charities" as components of the economy. Do not $A \& L$ have editors where they publish? There are of course individuals who shave themselves, shower themselves, feed themselves, dress themselves, instead of resorting to the market where they could hire barbers, bathroom attendants, butlers, maids, manservants, etc.

\section{Myth 4: Prices reflect value.}

A\&L maintain that "If the economy is a market, prices are what allow goods and services to be efficiently allocated. In Econ 101, because prices are set in 'free markets, ${ }^{3}$ the price of something must be a reflection of its real value." Nonsense. Prices are only accurate measures of scarcity value in equilibrium, where there are no profits and losses. In the real world of entrepreneurial error, prices are continually moving in that direction, but only theoretically ever attain it; in plain English, the real world economy is never in full equilibrium. One wonders if $A \& L$ ever sat through a real Econ 101 course themselves. Maybe they slept through the introduction to this subject.

On the basis of this misunderstanding of theirs, our authors berate the profession because "virtually no economist ... including Ben Bernanke and Alan Greenspan ... sounded the alarm ... in the run-up to the Great Recession (regarding) real house prices..."

This, it cannot be denied, is a good criticism of mainstream economists, who live and die by predication, and failed dismally on this occasion as A\&L perceptively note. But it does not so much as lay a glove on Austrianism, which eschews prediction. However, paradoxically, there were numerous praxeological practitioners who did indeed make this prediction (Block, 2010), albeit not as praxeologists of course, but rather as 
economic historians, commentators and journalists (e.g., thymologists).

\section{Myth 5: All profitable activities are good for the economy.}

A\&L sneeringly opine "Another axiom of Econ 101 is the assumption that all profitable activities are good for the economy." This is indeed true, but only with some provisos. No one thing can be good for the entire economy, which consists of billions of people. But every commercial action between the two parties involved is profitable for both of them, at least in the ex ante sense. To make sense of this claim, we must also posit that the exchange took place voluntarily, with no duress involved (Rothbard, 1997E). If "the economy" consists of the concatenation of all such business interactions, then, yes, not only are "all profitable activities ... good for the economy," but all purchases, sales, rentals, etc., are, too. Ain't the "magic of the market" great?

A\&L dismiss Adam Smith who did not at all '"prove...' that pursuit of self-interest maximizes economic welfare." Rather, he offered the insight of the invisible hand, that when pursuing his own self-interest, the market leads the businessman to enrich others, an astoundingly important vision. For a critique of Smith based on the claim he did not go far enough in his support of free enterprise, see Rothbard, 1987.

A\&L are particularly bitter about "pure rents (profiting from real estate appreciation, stock manipulation or the accident of owning mineral deposits that become more valuable) ... financial arbitrage, gambling in real estate or exploiting crony-capitalist political connections." But all of these are fully compatible with our understanding that mutually agreed upon trades are beneficial to all parties, given the provisos mentioned above. When real estate appreciates, the person who sells it, not less than the purchaser, gain. Successful arbitrage merely implies bringing goods from areas where it is less valued, and hence lower priced, to places where it is more valued, and hence higher priced. The welfare of all market participants improves when speculators save grain to ward off a famine, even though when they do so, they sell at a high price. A\&L do not seem to realize that "crony-capitalist political connections" are not really part of the free enterprise system. Rather, they are the diabolical very opposite of laissez faire capitalism; e.g., fascism.

Were these authors in my own Econ 101 class, I fear they would not earn a very high grade for there are several other errors in this section. A\&L think that "Mafia contract killing" can't be profitable, but it most certainly is in the ex-ante sense, at least for the killer and the person who took out the contract, otherwise they would not have done so. However, this certainly does not apply to the victim, but then he was not part of the commercial arrangement. A similar analysis applies to "prostitution and drug use." Both of these are engaged in by consenting adults who expected to gain from the transaction.

Our authors opine: "But the version of Econ 101 familiar to most politicians and pundits ignores the distinction between productive activities (e.g., making useful appliances or lifesaving vaccines) and pure rents (profiting from real estate appreciation, stock manipulation or the accident of owning mineral deposits that become more valuable). If the greatest fortunes are to be made in financial arbitrage, gambling in real estate or exploiting crony-capitalist political connections, the argument that private profit-seeking maximizes economic welfare and the public good is undermined."

There is a bit of a straw man argument here. No one ever said that crime is good for the economy. Even Keynesians (1936) such as Krugman (McKenzie, 2003; Murphy, 2012; Powell, 2001) who misunderstand the broken window fallacy and think that there are economic blessings from destruction do not see criminal activity in the same light. One of the many weaknesses of $A \& L$ is that they are strong on accusations, weak on documentation.

\section{Myth 6: Monopolies and oligopolies are always bad because they distort prices.}

State our authors: "In the abstract universe of Econ 101, monopolies and oligopolies are always bad because they distort prices... The neoclassical vision of the normal economy with 
multiple small yeoman producers resonates with Jeffersonian antitrust policy, with its suspicion that all large enterprises must be conspiracies against the public."

I may have to revise their grade in my course in a sharply upward direction, for A\&L do indeed here land a knock-out blow against most members of the economics profession, but not, of course, the Austrians. The mainstream computes four firm concentration ratios, and Herfindahl indices, and on the basis of them condemn large sized firms, even if they attained this status through purely market means; for a critique of this misbegotten analysis, see Anderson, et. al., 2001; Armentano, 1999; Barnett, et. al., 2005, 2007; Block, 1977, 1982, 1994; Block and Barnett, 2009; Boudreaux and DiLorenzo, 1992; Costea, 2003; DiLorenzo, 1996; DiLorenzo and High, 1988; Henderson, 2013; High,1984-1985; McChesney, 1991; McGee, 1958; Rothbard, 2004; Shugart, 1987; Smith, 1983; Tucker, 1998A, 1998B. But our authors lose a few points when they mention "temporary monopolies based on technological innovation." There are no such things. A monopoly is a government grant of privilege; technological innovation renders firms responsible for them, rather, single sellers.

\section{Myth 7: Low wages are good for the economy.}

A\&L inform us: "According to Econ 101, high wages are bad for an economy and low wages are a blessing. James Dorn of the libertarian Cato Institute declares that higher wages, by causing less demand for workers, mean that 'unemployment will increase ... No legislator has ever overturned the law of demand.' High-wage countries, we are told, price themselves out of a supposed global labor market."

But these authors completely misconstrue Dorn (2013). He was discussing not "high wages," but wages artificially raised by legislative fiat, such as the minimum wage law. Points off A\&L's grade for this egregious misreading of Dorn's very clear text.

There is nothing at all the matter with very high wages, as occur in Silicon Valley, Hollywood or Manhattan. Rather, this is evidence of extremely high productivity. Nor is there anything problematic per se about low wages either. These signal low productivity (the cause of this unhappy state of affairs is almost always unwise government intervention into the economy (Gwartney, et. al, 1996)). The difficulty is with wages that are artificially raised, or lowered for that matter, via minimum or maximum wage laws. Wage rates have a role to play in an economy. Under economic freedom, they always tend to reflect relative scarcity and productivity. It is only when government interferes in the market process that this sort of economic inefficiency raises its ugly head.

\section{Myth 8: "Industrial policy" is bad.}

Our authors aver: "Econ 101 tells us that letting markets determine how many 'widgets' to produce maximizes efficiency. The worst thing government can do is engage in 'industrial policy' - a catchall pejorative used to discredit everything from funding solar energy companies to encouraging more college students to major in science." A\&L write as if all introductory textbooks fully support laissez faire capitalism. Nothing could be further from the truth. Perhaps these writers have never read any of Econ 101 texts, at least not very carefully. Very much to the contrary, the mainstream textbook authors see market failures everywhere, all of which are in need of "industrial policy" to correct them. They see externalities, public goods, inequalities of wealth and income, lack of perfect competition, and much more, all requiring government action. Happily, this does not at all apply to Austrian texts (Callahan, 2004; Gordon, 2000; Murphy, 2007, 2010; Skousen, 2008; Taylor, 2011).

A\&L note that "banks issued trillions of dollars of bad loans leading to the financial crisis." True enough. But this was the result of the very "industrial policy" favored by them, for banking is one of the most highly regulated industries of all.

Our authors continue: "... for many investments private and public rates of return differ, often quite significantly. And unless society (through government) tilts investment to those activities where the public rate of return is higher (e.g., scientific research), growth will be less." Yes, if the bureaucrats could successfully "pick winners" or earn large profits, it is at least conceivable they could short-circuit the very imperfect market (which has profits as well as losses, ex post) and 
bring about greater efficiency. One wonders why oh why these authors think this is the case? Certainly, statist investors do not benefit from the weeding out process of the market (Hazlitt, 2008), where success is rewarded, and failure penalized. Anyone remember the failed Solyndra subsidies?

\section{Myth 9: The best tax code is one that doesn't pick winners.}

According to A\&L, "Econ 101 disparages industrial policy, even, or perhaps especially, when it is used in the tax code." Again, this is a misreading of introductory economics texts. They are replete with schemes for carbon taxation, taxes to promote egalitarianism, education, etc. Indeed, virtually every economics 101 text book urges, supports, defends, demands such industrial policy on grounds of combatting the so-called "market failure" of externalities. For example, introductory textbooks argue in favor of taxes on products that create so-called external diseconomies of pollution, and in favor of subsidies on industries that presumably foster positive externalities such as education. If that is not picking winners (and losers) then nothing is.

\section{Myth 10: Trade is always win-win.}

Our economic illiterates characterize "comparative advantage" as a "fairy tale." Why? Because "nations like America, Britain, Germany and Japan have used national industrial policies over the past century to become industrial powerhouses." Not so, not so. Yes, these countries engaged in tariff protectionism, but grew despite these malicious practices, not because of them.

No textbook ever claimed that "the location of factories and innovative research complexes is (always) determined by comparative advantage. Increasingly it is the artificial outcome of negotiations among multinational corporations and territorial states." Yes, yes. But to call our real world mercantilist system "free trade" bespeaks economic illiteracy to an astounding degree.

\footnotetext{
4 Boettke does make the following statement: "Economics has the same ontological status as physics --- reality is not optional --- but the 'laws' of economics are derived following different
}

\section{BOETTKE}

Boettke (2013) makes several telling criticisms of $\mathrm{A} \& \mathrm{~L}$, but as we have already discussed the many and serious errors of the latter, I move to do so for the former. There are fewer fallacies here, but they are as grave if not more so. The main difficulty is that Boettke (continually) analogizes economics to physics: "One must always remember that simple economics -- basic principles derived from the logic of action in a world of scarcity -- is not simpleminded. Critics of economics have forever tried to paint Econ 101 into such a corner --- unrealistic and unhelpful for the real world. How would we react if someone actually said something similar about physics?"

While this would not at all present any issue for the orthodox economist, who labors under a severe case of "physics envy," (Barnett, 2008, p. 140, fn. 20; Clark and Primo, 2012; Mises, 1978, 1998; Prowse, 1996; Rothbard, 1960, 1992, 1997A, 1997B; Taleb, 2010, p. 184; Terrell, 2010) it is a devastating concession for any Austrian economist to make, such as Boettke. It is not as if what this scholar is getting at here is not understandable: he is making the case that just as those who violate the findings of physics come to no good ends, the exact same thing applies to economics: "But make no mistake about it, the denial has the same impact on the "laws" of economics as the denial of the 'laws' of physics would by a man about to jump off the top of building would on the inevitable impact. All his denials will not mean much when he hits the pavement."

But it makes no sense to give the entire store away even in a worthwhile attempt to undermine A\&L. Methodological dualism is one of the very basic building blocks of the entire praxeological edifice. There are gigantic and stupendous differences, at least for Austrians, between the laws of economics and the "laws" of physics. Indeed, there is no such thing as the latter. To deny a synthetic apriori statement in economics is to commit a veritable

epistemological procedures. This is really nothing more, or less, than what Aristotle taught about methods of analysis being chosen based on appropriate." This cannot be denied. But it does not at all obviate the claim made in the text. 
logical contradiction. The same does not at all apply to physics. The so called "law" of gravity is merely a hypothesis. Yes, a lot rests on it; it is certainly a highly accepted hypothesis. But as scientists we must hold ourselves open to the possibility of it one day being contradicted. If so, there will be no violation of the laws of logic. However, it is logically impossible for the same thing to occur in the realm of economics, any more than within geometry, or other areas of mathematics or symbolic logic. Austrian methodology is predicated on this vast divergence, and Boettke runs roughshod over it.

States Rothbard, 1985 in this regard:

"At the heart of Mises and praxeology is the concept with which he appropriately begins Theory and History: methodological dualism, the crucial insight that human beings must be considered and analyzed in a way and with a methodology that differs radically from the analysis of stones, planets, atoms, or molecules. Why? Because, quite simply, it is the essence of human beings that they act, that they have goals and purposes, and that they try to achieve those goals. Stones, atoms, planets, have no goals or preferences; hence, they do not choose among alternative courses of action. Atoms and planets move, or are moved; they cannot choose, select paths of action, or change their minds. Men and women can and do. Therefore, atoms and stones can be investigated, their courses charted, and their paths plotted and predicted, at least in principle, to the minutest quantitative detail. People cannot; every day, people learn, adopt new values and goals, and change their minds; people cannot be slotted and predicted as can objects without minds or without the capacity to learn and choose."

Thus, Boettke (2013) in his otherwise admirable and accurate rejoinder to $\mathrm{A \& L}$, does the Austrian economics movement no little harm by conflating such an important distinction with his particularly inept analogy between economics and physics. Praxeology is in great part built on an utter renunciation of the similarity between the two, and Boettke (2013) needlessly and mistakenly brings them together.
If this author had mentioned "physics" on one occasion, we might be tempted to overlook his mistake as a sort of typographical error. But he mentions it in this short passage no fewer than five times. It is thus difficult to dismiss this as a slip of the tongue, or the fingers on the keyboard.

He continues with his conflation of these two very different universes of discourse:

"To go back to my physics talk --- if you drop a feather from the top of a building it may very well float up first before coming down to the ground, but nobody would believe that means that the "law of gravity" was being overturned. Same in economics; there are off-setting factors that in the basic logic are assumed to be held aside for the sake of analysis. However, when applying the 'laws' of economics to public policy, these off-setting factors must be taken into account [Just as in applying physics, the engineer must take into account factors such as wind resistence (sic) etc.]. In economics, this is where Institutional Analysis comes into play. An appropriate institutional economics does not critique the science of economics, but provides the bridge between the science of economics and the art of political economy."

Boettke quite rightly placed quotation marks around "law of gravity," since there is no such thing. If we adhere strictly to the proviso of the logical positivists (for a critique from an Austrian perspective, see Gordon, 1996, 2011; Long, Undated; Mises, 1978; Richards, 2009; Rothbard, 1992), this "law" is only a hypothesis, albeit a very strongly held one, based on much evidence. When the feather does not immediately drop, we of course surmise an upward wind draft or some such (or a magnet in the feather and some chicanery from an airplane above). A similar occurrence occurs in economics all the time, which is why we employ the ceteris paribus assumption, and jokes about chemists, physicists and economists marooned on islands with cans of food and no can openers. Nonetheless it is imperative, at least for Austrians, to maintain the methodological distinction between the two very different academic disciplines. 
It is more than passing curious that Boettke employs the same scare quotes for the "laws" of economics. Does he not accept methodological dualism? Synthetic apriori laws? The basic tenets of praxeology? If not, it is hard to understand why he would be counted as an Austrian economist. If yes, it is difficult to comprehend his continual use of the fallacious physics metaphor to expound upon economics.

I said above that Boettke's confusion between the methodology of physics and economics was his major error. What is his minor one? He states:

"Great teachers of economics, such as Henry Simons and Ludwig von Mises, believed that one of our primary tasks as economists was to dispel the public of popular fallalcies (sic)."

There is no problem, from this quarter, with regard to Mises. I fully support Boettke's contention there.
But Simons? I have no idea as to the quality of his lecturing, but I quarrel with this characterization of Boettke's as a "great teacher," since a necessary condition for that would be a sound knowledge of economics. Rothbard (2012) and Block (2002) make the case that Simon misunderstands the important economic concepts of monopoly, antitrust, competition, price cutting, free association. North (2012) makes similar points regarding money, banking and macroeconomics.

\section{CONCLUSION}

A\&L (2013) make some very good criticisms indeed against Econ 101 as taught by mainstream neo-classical economists, although most of them miss their mark. They fail dismally with regard to the Austrians. Boettke (2013) succeeds in correcting A\&L (2013), but falls victim, himself, to an important fallacy: conflating the proper study of economics and physics.

\section{REFERENCES:}

Atkinson R. and Lind, M. (2013). "Econ 101 is killing America: Forget the dumbed-down garbage most economists spew. Their myths are causing tragic results for everyday Americans." July 8; http://www.salon.com/2013/07/08/how_\%E2\%80\%9Cecon_101\%E2\%80\%9D_is_killing_ameri $\mathrm{ca} /$ ?utm_source=Email\&utm_medium=PPE\&utm_campaign=-Newsletter

Alston, R. M., Kearl, J. R. and Vaughan, M. B. (1992). "Is there a global economic consensus: Is there a consensus among economists in the 1990's?" AEA Papers and Proceedings; 203-209. http://www.weber.edu/wsuimages/AcademicAffairs/Provostltems/global.pdf

Anderson, W., Block, W.E., DiLorenzo, T.J., Mercer, I., Snyman, L. and Westley, C. (2001). "The Microsoft Corporation in Collision with Antitrust Law," The Journal of Social, Political and Economic Studies, 26 (1), 287-302

Armentano, D. T. (1999). Antitrust: The Case for Repeal. Revised $2^{\text {nd }}$ ed., Auburn, AL: Mises Institute

Barnett, W. II. (2008). "Operators are not Parameters, the Dimensions of Operators and Variables Must be Invariant, and Indices may not be Dimensioned: Rejoinder to Professors Folsom and Gonzalez." Quarterly Journal of Austrian Economics, 11, 132-143

Barnett, W., Block, W.E., and Saliba, M. (2005). "Perfect Competition: A Case of 'Market-Failure,"' Corporate Ownership \& Control. 2 (4), 70-75

Barnett, W. II, Block, W. E. and Saliba, M. (2007). "Predatory pricing." Corporate Ownership \& Control, 4 (4), 401-406

Batemarco, R. (1985). "Positive Economics and Praxeology: The Clash of Prediction and Explanation," Atlantic Economic Journal, 13(2), 31-27.

Block, W. E. (1973). "A Comment on 'The Extraordinary Claim of Praxeology,' by Professor Gutierrez," Theory and Decision, 3 (4), 377-387

Block, W. E. (1977). "Austrian Monopoly Theory -- a Critique," The Journal of Libertarian Studies, I (4), 271-279.

Block, W. E. (1980). "On Robert Nozick's 'On Austrian Methodology'." Inquiry, 23 (4), 397-444

Block, W. E. (1982). Amending the Combines Investigation Act, Vancouver, BC, Canada: The Fraser Institute.

Block, W.E. (1994). "Total Repeal of Anti-trust Legislation: A Critique of Bork, Brozen and Posner, Review of Austrian Economics, 8 (1), 35-70. 
Block, W. E. (1996). "Labor Market Disputes: A Comment on Albert Rees' 'Fairness in Wage Distribution,"' Journal of Interdisciplinary Economics, 7 (3), 217-230

Block, W. E. (1999). "Austrian Theorizing, Recalling the Foundations: Reply to Caplan," Quarterly Journal of Austrian Economics, 2 (4), 21-39

Block, W. E. (2000). "Heritage Stumbles on Minimum Wage," The Free Market, 18 (10); http://www.mises.org/freemarket_detail.asp?control=324

Block, W. E. (2001). "The Minimum Wage: A Reply to Card and Krueger," Journal of The Tennessee Economics Association, Spring, http://www.walterblock.com/wpcontent/uploads/publications/block_minimum-wage-once-again_2001.pdf

Block, W. E. (2002). "Henry Simons Is Not A Supporter of Free Enterprise," Journal of Libertarian Studies, $16(4), 3-36$

Block, W. E. (2010). "Austrian Thymologists Who Predicted the Housing Bubble." December 22; http://www.lewrockwell.com/block/block168.html

Block, W.E. and Barnett, W. II. (2002). "The Living Wage: What's Wrong," Ideas on Liberty, 52 (12) 2324; http://www.fee.org/publications/the-freeman/article.asp?aid=4533

Block, W.E. and Barnett, W. II . (2009). "Monopsony Theory." American Review of Political Economy, 7(1/2), 67-109

Block, W. E. and Cappelli, P. (2013). "Debate over the normative positive distinction in economics." Economics, Management, and Financial Markets 8(1), 11-19

Block, W. E., Dauterive, J and Levendis, J. (2007). "Globalization and the Concept of Subsistence Wages." Journal of Income Distribution. 16 (1), 74-88

Block, W. E. and Walker, M. A. (1988). "Entropy in the Canadian Economics Profession: Sampling Consensus on the Major Issues," Canadian Public Policy, XIV (2), 137-150.

Boettke, P. (2013). "Econ 101 is What is Needed Most." July 9;

http://www.coordinationproblem.org/2013/07/econ-101-is-what-is-neededmost.html?utm_source=Email\&utm_medium=PPE\&utm_campaign=Newsletter

Boudreaux, D. J., and DiLorenzo, T. J. (1992). "The Protectionist Roots of Antitrust," Review of Austrian Economics, 6 (2), 81-96

Buchanan, J. M., and Tullock, G. (1962). The Calculus of Consent: Logical Foundations of Constitutional Democracy, Ann Arbor, MI: University of Michigan.

Callahan, G. (2004). Economics for Real People: An Introduction to the Austrian School, Auburn: AL, Ludwig von Mises Institute

Caplan, B. (2007). The Myth of the Rational Voter: Why Democracies Choose Bad Policies. Princeton, $\mathrm{NJ}$ : Princeton University Press

Caplan, B. (2012). "IGM, Economic Consensus, and Partisan Bias." July 27; http://econlog.econlib.org/archives/2012/07/igm_and_economi.html

Clark, K. A and Primo, D. M. (2012). "Overcoming 'Physics Envy" New York Times Sunday Review; March 30; http://www.nytimes.com/2012/04/01/opinion/sunday/the-social-sciences-physicsenvy.html?_r=1

Costea, D. (2003). "A Critique of Mises's Theory of Monopoly Prices." The Quarterly Journal of Austrian Economics. 6 (3), 47-62

DiLorenzo, T. J. (1996). "The Myth of Natural Monopoly," Review of Austrian Economics, 9 (2), 43-58

DiLorenzo, T. J. and High, J. (1988). "Antitrust and Competition, Historically Considered," Economic Inquiry, 26 (1), 423-435

Dorn, J. A. (2013). "The minimum wage delusion, and the death of common sense." Forbes. May 7

Fox, G. (1992). "The Pricing of Environmental Goods: A Praxeological Critique of Contingent Valuation," Cultural Dynamics, V (3), 245-259

Frey, B. S., Pommerehne, W. W., Schneider, F. and Gilbert, G. (1984). "Consensus and Dissension Among Economists: An Empirical Inquiry, American Economic Review, 74 (5), 986-994.

Friedman, M. (1953). "The Methodology of Positive Economics," in Essays in Positive Economics, Chicago, IL: University of Chicago Press

Fuller, D., and Geide-Stevenson, D. (2003). "Consensus amongst economists revisited." Journal of Economic Education. 34 (4), 369-378; 
Gordon, D. (1996). "The Philosophical Origins of Austrian Economics." Summer; http://mises.org/philorig/main.asp

Gordon, D. (2000). Introduction to Economic Reasoning. Auburn: AL: Ludwig von Mises Institute

Gordon, D. (2011). "Mises versus the German Historical School and the Logical Positivists." April 14; http://archive.mises.org/16486/gordon-lecture-mises-versus-the-german-historical-school-andthe-logical-positivists/

Gordon, R., and Dahl, G. B. (2013). "What Do Economists Think about Major Public Policy Issues? Views among Economists: Professional Consensus or Point-Counterpoint? American Economic Review: Papers \& Proceedings 103(3), 629-635

Greene, Z., Henry, S., Nathanson, C. and Block, W. E. (2007). "Negative Impacts of Minimum Wage and anti Sweatshop Legislation" Humanomics 23 (2), 83-92

Gwartney, J., Lawson, R. and Block, W. E. (1996). Economic Freedom of the World, 1975-1995. Vancouver, B.C. Canada: the Fraser Institute

Hazlitt, H. (2008 [1946]). Economics in One Lesson. Auburn, AL: Mises Institute

Henderson, D. R. (2013). "The Robber Barons: Neither Robbers nor Barons." Library of Economics and Liberty. March 4; http://www.econlib.org/cgibin/printarticle2.pl?file=Columns/y2013/Hendersonbarons.html

High, J. (1984-1985). "Bork's Paradox: Static vs Dynamic Efficiency in Antitrust Analysis," Contemporary Policy Issues, 3, 21-34.

Hoppe, H. H. (1989). "In Defense of Extreme Rationalism: Thoughts on Donald McClosky's The Rhetoric of Economics," Review of Austrian Economics, 3, 179-214

Hoppe, H. H. (1994). "Austrian Rationalism in the Age of the Decline of Positivism," in Austrian Economics: Perspectives on the Past and Prospects for the Future, Vol. 17, Richard M. Ebeling, ed., Hillsdale, MI: Hillsdale College Press, 59-96.

Hoppe, H. H. (1992). "On Praxeology and the Praxeological Foundation of Epistemology and Ethics," Herbener, J., ed., The Meaning of Ludwig von Mises, Boston, MA: Dordrecht

Hoppe, H. H. (1995). Economic Science and the Austrian Method. Auburn, AL: The Ludwig von Mises Institute

Hoppe, H. H. (2006). "Austrian Rationalism in the Age of the Decline of Positivism" in The Economics and Ethics of Private Property: Studies in Political Economy and Philosophy, $2^{\text {nd }}$, ed., pp. 347379; Auburn, AL: The Mises Institute

Hülsmann, J. G. 1999. "Economic Science and Neoclassicism." Quarterly Journal of Austrian Economics, 2 (4), 1-20

Keynes, J. M. ([1936] 1964). The General Theory of Employment, Interest, and Money. New York, NY: Harcourt, Brace and World

Long, R. (Undated). "Wittgenstein, Austrian Economics, and the Logic of Action: praxeological investigations." http://mises.org/journals/scholar/long.pdf

MacKenzie, D. W. (2003). "Does Capitalism Require War?" April 7; http://mises.org/daily/1201/

McChesney, F. (1991). "Antitrust and Regulation: Chicago's Contradictory Views," Cato Journal, 10.

McCormick, P. and Block, W. E. (2000). "The Minimum Wage: Does it Really Help Workers," Southern Connecticut State University Business Journal, 15 (2), 77-80;

McGee, J. S. (1958). "Predatory Price Cutting: The Standard Oil (New Jersey) Case," The Journal of Law and Economics, 137-169

Mises, L. von. (1969). Theory and History: An Interpretation of Social and Economic Evolution. New Rochelle, NY: Arlington House.

Mises, L. von ([1962] 1978). The Ultimate Foundation of Economic Science: An Essay on Method. Kansas City, KS: Sheed Andrews \& McMeel.

Mises, L. von. (1998 [1949]). Human Action: The Scholar's Edition, Auburn, AL.: The Mises Institute

Murphy, R. P. (2007). The Politically Incorrect Guide to Capitalism. Chicago, IL: Regnery

Murphy, R. P. (2010). Lessons for the Young Economist. Auburn: AL: Ludwig von Mises Institute

Murphy, R. P. (2012). "The Broken-Window Fallacy." November 1; http://mises.org/daily/5593/

North, G. (2012). "How to End the Fed, and How Not To." September 10; http://mises.org/daily/6175/

Polleit, T. (2008). "Mises's Apriorism Against Relativism in Economics." April 25; 
http://blog.mises.org/archives/008051.asp

Polleit, T. (2011). "True Knowledge from A Priori Theory." June 8;

http://mises.org/daily/5349/True-Knowledge-from-A-Priori-Theory

Powell, B. (2001). "Is Terror Good for the Economy?" The Free Market. 19 (12), December; https://mises.org/freemarket_detail.aspx?control=372

Prowse, M. (1996). "Austrian Economics and the Public Mind." The Austrian Economics Newsletter, 16 (1), Spring; http://mises.org/journals/aen/aen16_1_1.asp

Richards, B. C. (2009). "Science Is as Science Does." March 11; http://mises.org/daily/3369/

Rizzo, M. (1979). "Praxeology and Econometrics: A Critique of Positivist Economics," New Directions in Austrian Economics, Louis Spadaro, ed., Kansas City, KS: Sheed Andrews and McMeel, pp. 40-56

Rothbard, M. N. (1951). "Praxeology: Reply to Mr. Schuller." American Economic Review, 41 (5), 943946.

Rothbard, M. N. (1957). "In Defense of Extreme Apriorism," Southern Economic Journal, 23(1), 314320.

Rothbard, M. N. (1960). "The Mantle of Science." Schoeck and Wiggins (eds.), Scientism and Values. Princeton, NJ: D. Van Nostrand Co., pp.159-180. Reprinted in Individualism and the Philosophy of the Social Sciences. San Francisco: Cato Institute (Cato Paper No. 4), 1979, pp. 1-27. Reprinted in Economistes et charlatans. Paris: Les Belles Lettres, 1991, pp. 3-36. Reprinted in The Logic of Action One: Method, Money, and the Austrian School. Glos, UK: Edward Elgar Publishing Ltd., 1997, pp. 3-23.

Rothbard, M. N. (1971). "Lange, Mises and Praxeology: The Retreat from Marxism." Toward Liberty. Vol. II, Menlo Park, CA: Institute for Humane Studies, pp. 307-321. Reprinted in The Logic of Action One: Method, Money, and the Austrian School. Glos, UK: Edward Elgar Publishing Ltd., 1997, pp. 384-396.

Rothbard, M. N. (1973). "Praxeology and the Method of Economics," Phenomenology and the Social Sciences, M. Natanson, ed., Evanston, IL: Northwestern University Press, vol. 2, p. 311 342; and Austrian Economics: A Reader Vol. 18, Richard M. Ebeling, ed., Hillsdale, Ml.: Hillsdale College Press, 1991, pp. 55-91.

Rothbard, M. N. (1976). "Praxeology: The Methodology of Austrian Economics," in The Foundations of Modern Austrian Economics. Edwin G. Dolan, ed., Kansas City: Sheed and Ward, pp. 19-39. http://www.econlib.org/library/NPDBooks/Dolan/dlnFMAContents.html

Rothbard, M. N. (1992). "The Present State of Austrian Economics." Working Paper from the Ludwig von Mises Institute, November. Reprinted in The Logic of Action One: Method, Money, and the Austrian School. Glos, UK: Edward Elgar Publishing Ltd., 1997, pp. 111-172. Reprinted in Journal des Economistes et des Etudes Humaines, Vol. 6, No. 1 (March 1995), pp. 43-89; http://mises.org/etexts/presentstate.pdf.

Rothbard, M. N. (1993). Man, Economy, and State, 2 vols., Auburn, AL: Ludwig von Mises Institute

Rothbard, M. N. (1985). "Preface to Theory and History by Ludwig von Mises." Auburn. The Mises Institute, http://mises.org/th/thpreface.asp; http://www.mises.org/th.asp

Rothbard, M. N. (1987). "The Celebrated Adam Smith." http://mises.org/page/1430

Rothbard, M. N. (1997A). "Praxeology as the Method of the Social Sciences," in The Logic of Action One. Murray N. Rothbard, ed., UK: Edward Elgar Publishing Limited, pp.28-57.

Rothbard, M. N. (1997B). "Praxeology: The Methodology of Austrian Economics," in The Logic of Action One. Murray N. Rothbard, ed., UK: Edward Elgar Publishing Limited, pp.58-77.

Rothbard, M. N. (1997C). "Praxeology, Value Judgments, and Public Policy," in The Logic of Action One. Murray N. Rothbard, ed., UK: Edward Elgar Publishing Limited, pp.78-99.

Rothbard, M. N. (1997D). "In Defense of 'Extreme Apriorism'," in The Logic of Action One. Murray N. Rothbard, ed., UK: Edward Elgar Publishing Limited, pp.100-108; http://mises.org/rothbard/extreme.pdf

Rothbard, M. N. (1997E). "Toward a Reconstruction of Utility and Welfare Economics," in The Logic of Action: Method, Money and the Austrian School, Vol. I, Cheltenham, UK: Edward Elgar, pp. 211-254 
Rothbard, M. N. (2012). "Competition and the Economists." Quarterly Journal of Austrian Economics. Vol. 15, No. 4, Winter, pp. 396-409; http://mises.org/journals/qjae/pdf/qjae15_4_11.pdf

Rothbard, M. N. (2004 [1962]). Man, Economy and State, Auburn AL: Ludwig von Mises Institute, Scholar's Edition; http://www.mises.org/rothbard/mes.asp

Ruccio, D. (2013). "Minimum wage." March 6; http://rwer.wordpress.com/2013/03/06/economics-is-ascience/

Schuldt, R., Woodall, D. and Block, W. E. (2012). "Drowning the Poor in Excessive Wages: The Problems of the Minimum Wage Law" Humanomics, 28 (4), 258 - 269;

Selgin, G. A. (1988). "Praxeology and Understanding: An Analysis of the Controversy in Austrian Economics," Review of Austrian Economics, (2), 19-58; and Praxeology and Understanding, Auburn, AL: Ludwig von Mises Institute, 1990

Sohr, K. and Block, W. E. (1997). "Minimum Wage," Freeman, 47 (11), 681-682.

Shugart II, W. F. (1987). "Don't Revise the Clayton Act, Scrap It!," 6 Cato Journal, 925

Skousen, M. (2008). Economic Logic. Chicago, IL: Regnery

Smith, Jr., F. L. (1983). "Why not Abolish Antitrust?," Regulation, Jan-Feb, 23

Taleb, N. N. (2010). The Black Swan. New York, NY: Random House

Taylor, T. C. (2011). An Introduction to Austrian Economics. Auburn: AL, Ludwig von Mises Institute

Terrell, S.T. (2010). "Economics is ... easy." July 14; http://mises.org/daily/4571

Tucker, J. (1998A). "Controversy: Are Antitrust Laws Immoral?" Journal of Markets \& Morality. 1 (1), 7582

Tucker, J. (1998B). "Controversy: Are Antitrust Laws Immoral? A Response to Kenneth G. Elzinga." Journal of Markets \& Morality. 1 (1), 90-94;

Wolfers, J. (2012). "The Secret Consensus among Economists." June 25; http://www.freakonomics.com/2012/07/25/the-secret-consensus-among-economists/

Vuk, V. (2006). Professor Stiglitz and the Minimum Wage." September 4; http://mises.org/daily/2266

Received for publication: $\quad 19.05 .2014$

Revision received: $\quad 10.06 .2014$

Accepted for publication: $\quad$ 23.06.2014

\section{How to cite this article?}

Style - APA Sixth Edition:

Block, W. E. (2014, 07 15). Is econ 101 killing America? A critique of Atkinson and Lind, and Boettke. (Z. Čekerevac, Ed.) MEST Journal, 2(2), 10-22. doi:10.12709/mest.02.02.02.02

Style - Chicago Fifteenth Edition:

Block, Walter E. 2014. "Is econ 101 killing America? A critique of Atkinson and Lind, and Boettke." Edited by Zoran Čekerevac. MEST Journal (MESTE) 2 (2): 10-22. doi:10.12709/mest.02.02.02.02.

Style - GOST Name Sort:

Block Walter E Is econ 101 killing America? A critique of Atkinson and Lind, and Boettke [Journal] // MEST Journal / ed. Čekerevac Zoran. - Belgrade : MESTE, 07 15, 2014. - 2 : Vol. 2. - pp. 10-22.

Style - Harvard Anglia:

Block, W. E., 2014. Is econ 101 killing America? A critique of Atkinson and Lind, and Boettke. MEST Journal, 15 07, 2(2), pp. 10-22.

Style - ISO 690 Numerical Reference:

Is econ 101 killing America? A critique of Atkinson and Lind, and Boettke. Block, Walter E. [ed.] Zoran Čekerevac. 2, Belgrade : MESTE, 07 15, 2014, MEST Journal, Vol. 2, pp. 10-22. 